Jagiellonian University in Kraków, Poland

krzysztof.dziurzynski@gmail.com

DOI: $10.13166 / \mathrm{JMS} / 95080$

JOURNAL OF MODERN

EWA DudA

The Maria Grzegorzewska University

in Warsaw, Poland

duda.ewa@wp.pl

\title{
GRADE REPETITION AS A CONSEQUENCE OF SCHOOL FAILURES
}

\begin{abstract}
The solution of repeating a school grade when learners do not achieve required level of knowledge or skills has as many proponents as opponents. Numerous educational systems support a grade retention as the method of obtaining better learning outcomes. In the same time, others do not allow to repeat a school year and recommend automatic promotion. The growing problem of school failures, among them repeating a school grade or even dropouts, is still present in the academic discourse. This article presents the impact of school failures and its range from the point of view of learners attending Polish secondary school for adults.
\end{abstract}

KEYWORDS: grade repetition; grade retention; school failures; adult formal education.

\section{INTRODUCTION}

The terminology which the pedagogical discourse dealing with educational failures relies on so far has not been clearly defined. The expression "educational failure" is used interchangeably with such phrases as "school education delay," "educational-didactic failure," "educational difficulties", and "difficulties and failures in education."

Generally speaking, one could define the educational failure as "the condition which the child has found themselves in due to their failing to meet the school's requirements" (Konopnicki, 1966). 
The phenomenon of the education failure has also been described as "situations characterised by a noticeable disparity between the school's educational and didactic requirements and the conduct, as well as educational results, of the pupil" (Kupisiewicz, 2005).

Educational failures are defined as the disparity between the content, the abilities and the habits that the pupil has indeed acquired and that which he or she should have acquired according to the educational programme of the given subject (Kupisiewicz, 2005).

According to W. Okoń, grade repetition is one of the two (the other being the so-called "weeding") main types of the overt educational failure, and consists in a pupil being held in the same class for two or more years (Okoń, 2003). What grade repetition expresses is a disparity between the school's requirements and the pupil's achievement. Not only does it result in financial losses that the significant extension of school time for a considerable percentage of pupils entails but it has also serious pedagogical consequences related to the experience of grade repetition and its influence on the personality and the educational future of the pupils.

Educational failures are situations characterised by a noticeable disparity between the school's educational and didactic requirements and the conduct, as well as educational results, of the pupil (Kupisiewicz, 2005) - assuming, goes without saying, that the school's requirements are both in accordance with the educational goals accepted by the society and do not contradict the relevant educational programmes.

Although the issue of grade repetition is by no means new, it still arouses quite a bit of controversy. Each year thousands of pupils all over the world repeat the very same grade even though it is justified neither socially nor economically.

In a literature concerning the grade repetition we can find the examples of research that show some benefits of leaving students in the same grade instead of promote them with other peers. The research investigating early grade retention (Schwerdt \& West, 2012) presents that children repeating third grade in the subsequent school year have substantial achievements in mathematics and reading. The study points out as well the disappearing of this positive effect within five years. Benefits of repeating a year instead 
of social promotion are presented generally by examinations of early grade students (Greene, and Winters, 2017), however the scale of gains is rather small and questioned in terms of costs incurred. Besides of knowledge achievements, the proponents indicate that fear of repeating the year could enhance students' motivation and mobilize for learning (Squires, 2015).

In contrast to positive, the negative attitude toward the grade repetition is much more widespread among educational researchers. They show significant positive correlation between the grade retention and dropping out of high school and significant negative correlation between the grade retention and labour market earnings (Eide \& Showalter, 2001). From key predictors of school withdrawal, the grade repetition is the most significant one (Rumberger, 1995; Alexander et al., 2001; Jimerson, Anderson and Whipple, 2002). The major effects of flunking are: negative emotions toward subsequent learning, too crude necessity to repeat all subjects, the sense of stressful punishment, economic losses (Shepard and Smith, 1990).

Grade repetition is seen from two viewpoints - either as another stage of educational failures at school or as a means of counteracting the latter (Karpińska, 1999). More than fifty years ago Jan Konopnicki wrote: „The grade repetition is a nineteen-year-old organizational relic, harmful from every point of view, politically reverse and economically senseless" ["Drugoroczność jest dziewiętnastoletnim przeżytkiem organizacyjnym szkodliwym z każdego punktu widzenia, politycznie wstecznym, a ekonomicznie bezsensownym"] (Konopnicki, 1966, p. 166). In spite of there existing a great number of studies which indicate that such a method of counteracting education failures at school in the end brings about more harm than benefit and often only aggravates the existing problem, the grade repetition still has its advocates, especially amongst the contemporary professionally active teachers.

\section{RESEARCH METHODS}

The paper seeks to present the magnitude of as well as assess the problem of grade repetition seen as a consequence of educational failure. The basis for the research is the secondary data found in PISA 2009, Eurostat, UNESCO Institute for Statistics (UIS) and Central Statistical Office (CSO). 
The available secondary data pertain to the year 2017/2018 (PISA 2009, Eurostat), 2010 (Global Education Digest, 2012) and 2016/2017 (CSO, 2017).

The paper is also an opportunity to contemplate the educational difficulties faced by those who are attending adult schools and have experienced grade repetition earlier on. The participants in the research are the students of one of high schools for adults in Warsaw. Since the records of their earlier education stages proved difficult to come by, the research relied instead on the statements made by the respondents and used a diagnostic survey. The survey, prepared in such a way that it could diagnose the magnitude of the educational problems, was filled in by 93 students who attended one of the three grades of the high school; 48 of them were female and 45 male.

The next stage of the research relied on the method of focus interview, in which participated a randomly selected group of students who have had a personal experience of grade repetition. 13 persons, 7 of them female and 6 male, took part in the interview.

\section{SECONDARY ANALYSIS}

Grade repetition is used almost worldwide as a method to prevent educational failures. One ought to note, however, that the intensity of the phenomenon varies greatly. Some countries, such as Burundi, Morocco and Spain, tend to rely on it rather often, while others, notably Japan, Austria and Scandinavian countries, do not resort to it at all, or do so exceedingly rarely. Table 1 shows the percentage of primary school, middle school and high school pupils coming from the world's selected countries who repeat grades. One ought to bear in mind how different the educational policies are in the respective systems. In Burundi it is the primary school pupils who make up the greatest percentage of grade repeaters - and the percentage decreases as the education level increases. However, this is not because pupils succeed in achieving the required knowledge and ability levels but due to the significant drop-out rate (Verwimp et all., 2014). A positive linear correlation between the education level and the percentage of grade repeaters can be found in many countries (e.g., in Algeria, Spain, United Arab Emirates, Switzerland, the Netherlands). 
Table 1.

Primary and secondary education ( ISCED 1, 2 and 3), Repetition, 2010

\begin{tabular}{|c|c|c|c|c|c|c|c|c|c|c|c|}
\hline & Repeaters & \multicolumn{9}{|c|}{ Percentage of repeaters } \\
\hline & & \multirow{3}{*}{$\begin{array}{c}\begin{array}{c}\text { Primary } \\
\text { education }\end{array} \\
2 \\
\text { MF }(000)\end{array}$} & \multicolumn{3}{|c|}{$\begin{array}{l}\text { Primary } \\
\text { education }\end{array}$} & \multicolumn{3}{|c|}{$\begin{array}{l}\text { Lower secondary } \\
\text { (ISCED 2), } \\
\text { general } \\
\text { programmes }\end{array}$} & \multicolumn{3}{|c|}{$\begin{array}{l}\text { Upper secondary } \\
\text { (ISCED 3), } \\
\text { general } \\
\text { programmes }\end{array}$} \\
\hline \multicolumn{2}{|r|}{1} & & \multicolumn{3}{|c|}{3} & \multicolumn{3}{|c|}{4} & \multicolumn{3}{|c|}{5} \\
\hline Lp. & $\begin{array}{c}\text { Country } \\
\text { or territory }\end{array}$ & & MF & M & $\mathrm{F}$ & MF & M & $\mathrm{F}$ & MF & M & $\mathrm{F}$ \\
\hline 1. & Burundi & 623 & 34 & 34 & 34 & 25 & 24 & 27 & 18 & 17 & 19 \\
\hline 2. & Morocco & 424 & 11 & 13 & 9 & 15 & 18 & 11 & 16 & 19 & 13 \\
\hline 3. & Algeria & 248 & 7 & 9 & 6 & 15 & 19 & 11 & 19 & 21 & 17 \\
\hline 4. & Tunisia & 70 & 7 & 8 & 5 & 18 & 22 & 14 & 16 & 17 & 15 \\
\hline 5. & Peru & 233 & 6 & 6 & 6 & 7 & 8 & 5 & 4 & 5 & 3 \\
\hline 6. & Luxembourg & 1 & 4 & 4 & 4 & 11 & 12 & 9 & 7 & 9 & 6 \\
\hline 7. & Spain & 72 & 3 & 3 & 2 & 13 & 15 & 12 & 14 & 16 & 13 \\
\hline 8. & Slovakia & 7 & 3 & 3 & 3 & 2 & 2 & 2 & - & - & - \\
\hline 9. & Belgium & 24 & 3 & 3 & 3 & 7 & 7 & 6 & 7 & 10 & 6 \\
\hline 10. & $\begin{array}{c}\text { United Arab } \\
\text { Emirates }\end{array}$ & 7 & 2 & 2 & 2 & 3 & 3 & 2 & 4 & 4 & 3 \\
\hline 11. & Switzerland & 7 & 1 & 2 & 1 & 2 & 2 & 2 & 4 & 5 & 4 \\
\hline 12. & Germany & 16 & 1 & 1 & - & 3 & 3 & 2 & 1 & 1 & 1 \\
\hline 13. & $\begin{array}{c}\text { Czech } \\
\text { Republic }\end{array}$ & 3 & 1 & 1 & 1 & 1 & 1 & 1 & - & 1 & - \\
\hline 14. & Estonia & - & 1 & 1 & - & 3 & 4 & 2 & 4 & 4 & 4 \\
\hline 15. & Guyana & 1 & 1 & 1 & - & 12 & 15 & 9 & 6 & 8 & 5 \\
\hline 16. & Chile & 16 & 1 & 1 & 1 & 1 & 1 & 1 & 2 & 2 & 2 \\
\hline 17. & Finland & 1 & - & 1 & - & 1 & 1 & - & . & . & . \\
\hline 18. & Denmark & 1 & - & - & - & 1 & 1 & 1 & 3 & 3 & 2 \\
\hline 19. & Croatia & - & - & - & - & 1 & 1 & - & 1 & 1 & - \\
\hline 20. & Japan & - & - & - & - & $\ldots$ & $\ldots$ & $\ldots$ & $\ldots$ & $\ldots$ & $\ldots$ \\
\hline 21. & Austria & - & - & - & - & - & - & - & - & - & - \\
\hline 22. & Liechtenstein & - & - & - & - & - & - & - & - & - & - \\
\hline
\end{tabular}




\begin{tabular}{|c|c|c|c|c|c|c|c|c|c|c|c|}
\hline \multicolumn{2}{|c|}{1} & 2 & \multicolumn{3}{|c|}{3} & \multicolumn{3}{c|}{4} & \multicolumn{3}{c|}{5} \\
\hline 23. & Sweden & - & - & - & - & - & - & - & - & - & - \\
\hline 24. & Netherlands &. &. &. &. & 4 & 4 & 3 & 9 & 10 & 8 \\
\hline 25. & Norway &. &. &. &. &. &. &. & $\ldots$ & $\ldots$ & $\ldots$ \\
\hline \multicolumn{10}{|c|}{ Not applicable } & $\ldots$ & \multicolumn{2}{|c|}{ No data available } & - & \multicolumn{3}{c|}{$\begin{array}{c}\text { Magnitude nil or neg- } \\
\text { ligible }\end{array}$} \\
\hline
\end{tabular}

Source: Own elaboration based on UNESCO Institute for Statistics (2012). Opportunities lost: The impact of grade repetition and early school leaving. Global Education Digest 2012, pp.110-113.

One may infer from a comparative analysis of the grade repetition of Polish pupils against the grade repetition in other European countries (figures 1 and 2) that the situation in Poland is rather far from bleak. The data is generally presented in terms of relative value and as such suggests that the magnitude of serious educational failures in Polish schools is negligible.

Figure 1.

Estimate of grade retention at primary and secondary level ( ISCED 1 and 2), $2007 / 2008$ [\%]

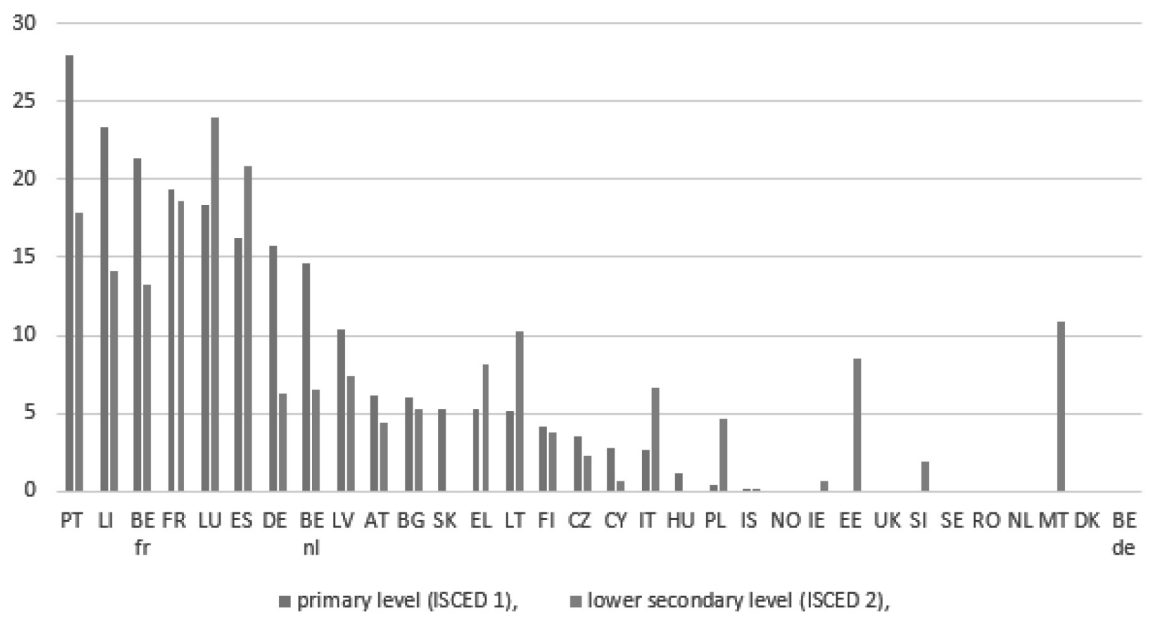

Source: Own elaboration based on Eurydice, (2011). Grade Retention during Compulsory Education in Europe: Regulations and Statistics. Brussels: Education, Audiovisual and Culture Executive Agency 
According to the research carried out by EACEA (Eurydice, 2011) on the basis of the relevant Eurostat data, in the year 2007/2008 the percentage of Polish pupils who failed to proceed to the next primary school grade did not exceed $0,4 \%$; amongst middle school pupils it reached $4,6 \%$. The same study provides also the data pertaining to those fifteen-year-olds who have repeated a grade at least once. In the primary school the percentage is $1,9 \%$ of pupils and in the middle school 3,9\%, which is still well below the European average, which is respectively $7,7 \%$ and $10,4 \%$.

Figure 2.

Proportion of 15-year-old pupils who have repeated a year at least once at primary and secondary level ( ISCED 1 and 2) in reference to country, 2009 [\%]

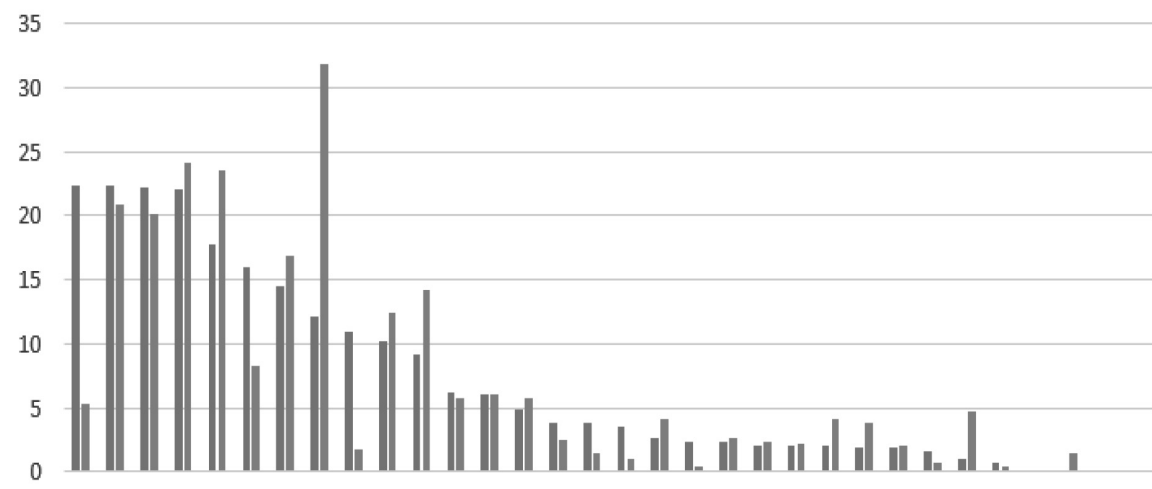

NL PT LU BE FR BE BE ES IE LI DE HU LV AT EE SE DK BG FI RO CZ LT EL PL SK UK IT IS NO SI MT CY fr $\mathrm{nl}$ de

- in primary education (ISCED level 1) $\quad$ at lower secondary level (ISCED 2)

Source: Own elaboration based on Eurydice, (2011). Grade Retention during Compulsory Education in Europe: Regulations and Statistics. Brussels: Education, Audiovisual and Culture Executive Agency

The magnitude of the problem can also be seen from another angle. If we place the number of students who have experienced a serious educational failure in the context of all the European fifteen-year-olds taking part in the PISA 2009 survey, it turns out that the Polish education system "generates" a significant portion of such pupils. The results of an analysis of the PISA 2009 data (Figure 3), just like the EACEA study 
(Eurydice, 2011), fail to take into account the pupil's refusal to respond to the survey (ranging from $0,43 \%$ in Slovenia to $12,65 \%$ in Portugal). Pupils are often most reluctant to admit that they had to repeat a grade and do not mark the correct response, which is why the study is flawed and fails to adequately assess the magnitude of the problem.

Figure 3.

Proportion of 15-year-old pupils who have repeated a year at least once at primary and secondary level (ISCED 1 and 2) in reference to all pupils, 2009 [\%]

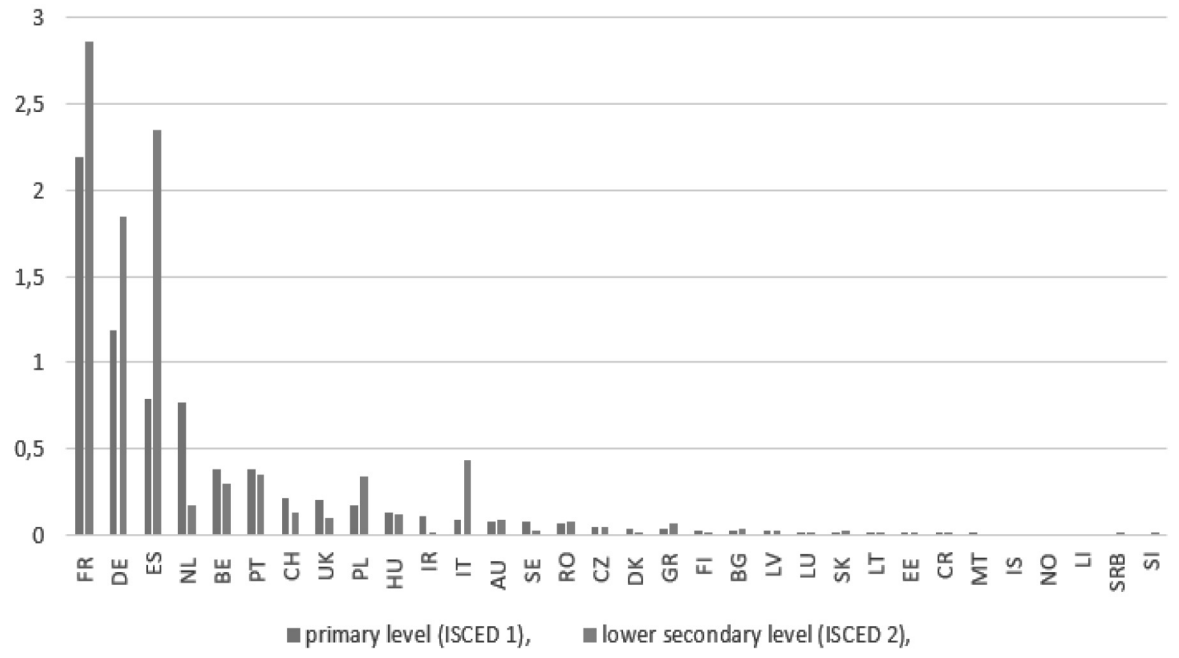

Source: Own elaboration based on data from PISA 2009. Accessed on 1st May 2018 from http:// www.oecd.org/pisa/data/pisa2009technicalreport.htm

The latest survey of Central Statistical Office indicates that in the year 2016/2017 22842 pupils (0,99\%) repeated a primary school grade (Figure 4) and 19095 pupils (1,78\%) repeated a middle school grade (Figure 4). The data cited does not pertain to the number/percentage of pupils who in the year 2016/2017 repeated a high school grade. 
Figure 4.

Pupils repeating the same grade in Polish primary schools (excluding special schools)

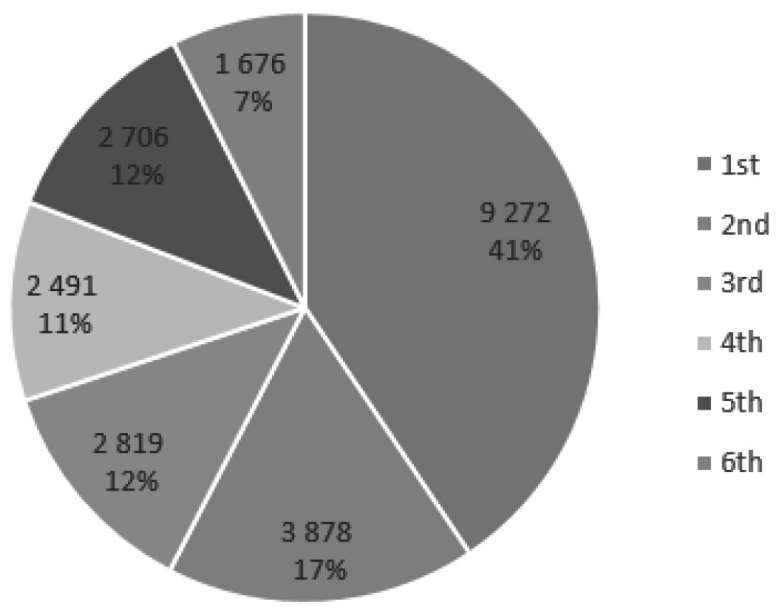

Source: Own elaboration based on Education in 2016/2017 School Year, CSO, Social Surveys and Living Conditions Department, Statistical Office in Gdańsk

Figure 5.

Pupils repeating the same grade in Polish lower secondary schools (excluding special schools)

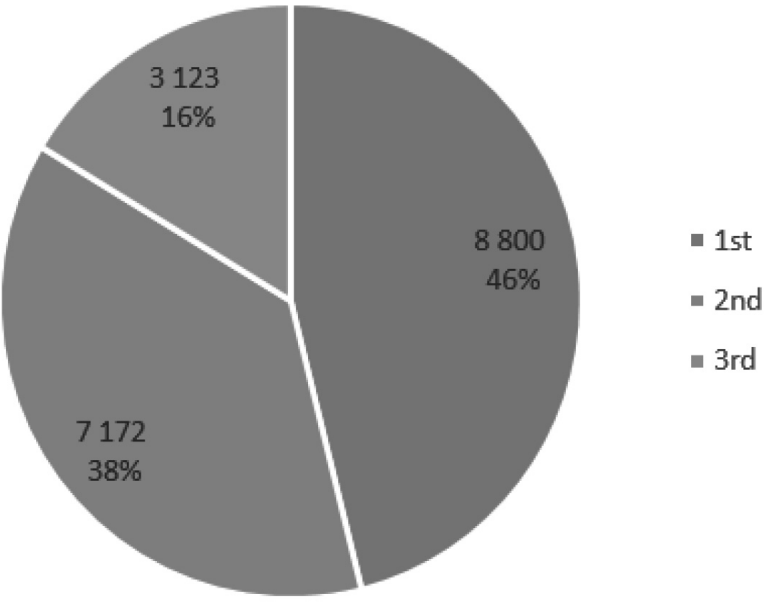

Source: Own elaboration based on Education in 2016/2017 School Year, CSO, Social Surveys and Living Conditions Department, Statistical Office in Gdańsk 
The Central Statistical Office data fails to include any information regarding the number/percentage of grade repeating learners who in the year 2016/2017 adult schools - which has prompted the authors of this paper to attempt a preliminary assessment of the magnitude of the problem of grade repetition in adult schools.

Adult schools are usually attended by those who experienced educational problems in youth schools or found it impossible to complete their education in a youth school due to chance factors - and who decide to learn part-time, so as to be able to both pursue their school education and work. The survey the authors of the paper conducted sought to assess what percentage of adult learners have personally experienced grade repetition. The results of the survey can be found in Table 2 .

Table 2.

Learners who have repeated the same grade at least once (chosen upper secondary school for adult)

\begin{tabular}{|c|c|c|c|c|c|}
\hline & $\begin{array}{l}\text { Learners } \\
\text { taking part } \\
\text { in survey }\end{array}$ & $\begin{array}{c}\text { Learners } \\
\text { who have } \\
\text { repeated } \\
\text { a year at least } \\
\text { once }\end{array}$ & $\begin{array}{c}\text { Learners who } \\
\text { have repeated } \\
\text { a year at least } \\
\text { once }\end{array}$ & $\begin{array}{l}\text { Learners } \\
\text { who have re- } \\
\text { peated a year } \\
\text { at least once }\end{array}$ & $\begin{array}{l}\text { Percentage } \\
\text { of learners } \\
\text { who have } \\
\text { repeated a year } \\
\text { at least once }\end{array}$ \\
\hline & $N$ & (M) & (F) & (Total) & $\%$ \\
\hline $1^{\text {st }}$ grade & 29 & 15 & 10 & 25 & 86.2 \\
\hline $2^{\text {nd }}$ grade & 25 & 8 & 11 & 19 & 76.0 \\
\hline $3^{\text {rd }}$ grade & 39 & 14 & 14 & 28 & 71.8 \\
\hline Grand total & 93 & 37 & 35 & 72 & 77.4 \\
\hline
\end{tabular}

Source: Own survey

Amongst those surveyed, more than $75 \%$ at least once repeated the very same grade. Six learners repeated a primary school grade. In this group, two persons were held up because of their failure to meet the class attendance requirement due to a prolonged illness, and three learners completed only (eight-year-long) primary school education, later on 
attending some vocational courses so as to make up for their abandoning the education path. Sixteen learners at least once repeated a middle school grade; the subjects which they most often failed included mathematics, chemistry, Polish language and physics, mathematics being clearly the dominant one. 58 learners repeated a high school grade, 8 of them repeating a grade both in middle and high schools; here once more the main reason behind repetition was their failure to learn what constitutes the core curriculum in mathematics, whereas physics, biology, business basics, Polish language and vocational subjects were of overall secondary importance in the group. 7 learners repeated a grade more than once.

\section{QUALITATIVE RESEARCH RESULTS}

The survey research allowed the authors of the present paper to assess the educational failure level of the surveyed adult high school learners. It also became a starting point for further research into not only the attitudes those who repeat grades have towards the phenomenon of grade repeating - but also the influence the latter exerts on their lives. The next stage of the study consisted in a focus group interview. The authors chose the method and the technique because a feature of the surveyed group is its good social relations. The friendly attitude towards each other as well as the natural openness of some of the persons surveyed encouraged those generally too shy to eagerly share their experience to actively join in.

What the learners surveyed said appears to corroborate the data found in numerous scientific meta-analyses devoted to the presentation of the negative influence of grade repetition. However, what features in the testimonies of those surveyed most prominently is the resentment they feel towards their teachers/school/family, and it is the latter three that are most often blamed for the failure that the learners experienced.

F1: I had to repeat the grade in another school - my teachers did not want me. I've no clue why they wouldn't want me, but what was I supposed to do? There was no point in asking them to let me stay, was there? So I just changed the school.

F2: When I was a second grader in middle school my mum died. Nobody even tried to offer any help. There was just one person back then who 
was all right, my chemistry teacher. I became very withdrawn, though. Some three months after my mum's death I was late for a class, and a teacher, not the chemistry teacher, he says: "Such a duffer, you are. So what, that your mum has died? Well love, get a grip on yourself! You're at school, not at some place of comfort!" Then I slammed the door, left the classroom and practically stopped coming to school.

M1: I'd had some problems at school earlier. The teachers would say: You just get your handbook, lad, and do some exercises! But how am I supposed to do exercises when I just don't understand a thing?

F3: Had I been taught in primary school by such teachers as the ones that we are having right now, nothing of it would have happened.

M4: I repeated several times the second grade of the middle school, due to my low marks. I reckon the teachers had it in for me.

F4: I have always been a quite one. The teachers would notice those pupils who were outgoing or tended to get high marks, they wouldn't see those with lower marks. I never felt at home there. I repeated the grade twice. The form tutor, she did not try to understand.

M6: I repeated the third middle school grade twice in a row. The mum had gone abroad for work, the stepfather would start drinking as soon as he woke up - me and my brother were on our own. We had always made trouble, respected no one, did whatever we wanted to. I guess it was sort of a way of running away from the problems at home. It was not that I was ill-disposed towards the school or the teachers, not at all. Rather it was all because of the family problems that I was trying to escape from.

The grade retention did not permanently contribute to raising the level of knowledge and skills of the students. Confirmation can be found in the following statements:

M2: I didn't learn no more, only later I didn't try to learn, but to somehow pass it. At the beginning it is a learning, and when you repeat the grade, the point is to pass what you did not have before, so as not to be in the same place again.

M3: As I repeated the class, maybe I learned a little more, but it did not matter that I would cope better with it, not really. 
Being forced to repeat a grade meant also negative impact upon the relations between the learners, as indicated by the following statements: F5: I had no friends in the new class. Everybody had known each other well, and being the newcomer I felt lonely - which is what made me stop attending. Then I went abroad in search for work.

M4: I repeated the second middle class grade. I messed up two subjects and I didn't go into the next year. The class had been amazing, we'd got on like a house on fire, I'd been doing fine, the teachers had been OK-ish, too - all perfect but for these two subjects, Polish language and history. I hadn't really want to learn that much. I had tried to re-sit the F subjects but had only failed again. The new class was not so cool.

Another result of preventing learners from going into the next year is their negative attitude towards the school and the teacher. The following statements might serve as examples here:

F6: Grade repetition cost me two years of my life during which my dislike of the school (that particular school, it's not that I hate learning or anything) only increased. As did the amount of stuff I should have learned but didn't.

F7: When I failed I grew tougher, is what I did. I wouldn't let anyone push me about anymore. When one of teachers said something I didn't care one bit. After the middle school I found myself a vocational school.

A frequent result of grade repetition is the increase in the negative behaviour, which is what appears to have been the experience of some of those the authors surveyed:

M5: There was nothing I cared about anymore, really. I'd go partying, get drunk and mess around with my mates. I'd not go to school unless there was nothing else I could do.

M6: Whenever I was sitting at school and not understanding a word of what was being said, I thought: how dense am I! I am going to fail it anyway so it doesn't matter a bit if I attend or skip classes. So I'd go out for a fag or muck about with me mates. When the new school year came I did not have it in me to even start attending. 


\section{Conclusions}

The data cited and the statements quoted show that grade repetition is a serious problem in the Polish school, which has failed to solve it about last 90 years. Grade repetition bears upon the attitude of the students towards their teachers and influences the way in which students perceive their school, themselves and the social relationships they are a part of. It has the huge impact on results of external examinations and tests that are based on matriculation examinations standards, which are significant is the formal education system (Dziurzyński, 2013; Wrzosek 2016). The school, which ought to be the place of student's development, becomes the source of complexes, the loss of student's self-confidence and the lack of trust in others.

The research conducted indicates that young adults - the learners at comprehensive schools for adults who have experienced numerous educational failures but decide to continue their education - ought to be the place of student's development, becomes the source of complexes, the loss of student's self-confidence and the lack of trust in others.

There is no form period with semester tutor in the schedule of the Polish adult school. The number of classes is generally the barest minimum possible, which in no way helps the learner who is falling behind to catch up with his peers. There is also no effective system of psychological support which young learners could rely upon. One could put forward here another (ceaselessly voiced since times immemorial) request addressed to the educational authorities to not so much resume a debate about the modernisation of the young adult education as implement, making use of the changes presently implemented to the Polish education system, a truly effective actions that would make it possible to undo the learner's earlier educational failures. This opportunity would give many young Polish learners the chance to have a better life, one less lacking in dignity, as well as encouraging them to perceive learning as a lifelong venture. 


\section{References:}

Alexander, K. L., Entwisle, D. R., \& Kabbani, N. S. (2001). The dropout process in life course perspective: Early risk factors at home and school. Teachers College Record 103(5), pp. 760-822. ISSN ISSN-0161-4681.

CSO (2017). Education in 2016/2017 School Year. Warsaw: Social Surveys and Living Conditions Department, Statistical Office in Gdańsk.

Dziurzyński, K. (2013). Rezultat sprawdzianu próbnego szóstoklasistów jako przykład praktycznej diagnozy kompetencji uczniowskich, „Journal of Modern Science” tom 2/17/2013. ISSN 1734-2031.

Eide, E.R. and Showalter, M.H. (2001). The Effect of Grade Retention on Education and Labor Market Outcomes. Economics of Education Review. 20(2001), pp. 563-576. ISSN 0272-7757.

Eurydice, (2011). Grade Retention during Compulsory Education in Europe: Regulations and Statistics. Brussels: Education, Audiovisual and Culture Executive Agency. ISBN 9789292011406, doi 10.2797/50570.

Greene, J. P and Winters, M. A. (2017). Revisiting Grade Retention: An Evaluation of Florida's Test-Based Promotion Policy. Education Finance and Policy 2(4), pp. 319-340. ISSN 1557-3060.

Jimerson, S. R., Anderson, G. E. and Whipple, A. D. (2002). Winning the battle and losing the war: examining the relation between grade retention and dropping out of high school. Psychology in the Schools 39(4), pp. 441-457. ISSN 1520-6807.

Karpińska, A. (1999). Drugoroczność: pedagogiczne wyzwanie dla wspótczesności. Białystok: Trans Humana. ISBN 8386696486.

Konopnicki, J. (1966). Powodzenia i niepowodzenia szkolne. Warszawa: Państwowe Zakłady Wydawnictw Szkolnych. ISBN 9788361612049.

Kupisiewicz Cz. (1964). Niepowodzenia dydaktyczne. Przyczyny i niektóre środki zaradcze., Warszawa PWN. ISBN 832210202798.

Kupisiewicz, Cz. (2005). Podstawy dydaktyki ogólnej, Warszawa, Wydawnictwa Szkolne i Pedagogiczne. ISBN 8302093106.

Okoń W., (2003). Wprowadzenie do dydaktyki ogólnej . Warszawa, Wydaw. Akademickie “Żak”. ISBN 838677021X.

Rumberger, R. W. (1995). Dropping out of middle school: A multilevel analysis of students and schools. American Educational Research Journal, 32 (3), pp. 583-625. ISSN 0002-8312. 
Schwerdt, G. and West, M.R. (2012). The Effects of Early Grade Retention on Student Outcomes over Time: Regression Discontinuity Evidence from Florida. Program on Education Policy and Governance Working Paper Series. PEPG 12-09.

Shepard, L. A. and Smith, M. L. (1990). Synthesis of Research on Grade Retention. Educational Leadership 47(8), pp. 84-88. ISSN 0013-1784.

Squires, J. H. (2015). Retention in the early years: Is early retention an effective, research-based strategy for improving student outcomes?. New Brunswick, NJ: Center on Enhancing Early Learning Outcomes.

UNESCO Institute for Statistics (2012). Opportunities lost: The impact of graderepetition and early school leaving. Global Education Digest 2012. Montreal. Accessed on $1^{\text {st }}$ May 2018 from http://uis.unesco.org/sites/default/files/documents/opportunitieslost-the-impact-of-grade-repetition-and-early-school-leaving-en_0.pdf

Verwimp, P., Cieslik, K., Giani, M., Muñoz Mora, J. C. and Ngenzebuke, R. L. (2014). Inequality in Education, School-dropout and Adolescent lives in Burundi. Université Libre de Bruxelles, UNICEF-Burundi. Accessed on $1^{\text {st }}$ May 2018 from http://solvay. edu/sites/upload/files/clean_report_educ_final3.pdf

Wrzosek T. (2016). Rola egzaminu maturalnego $w$ procesie edukacji - perspektywa uczestników projektów Centralnej Komisji Egzaminacyjnej. Raport z badania. „Journal of Modern Science” tom 2/29/2016. ISSN 1734-2031. 